\title{
UPPER PLEISTOCENE-HOLOCENE IN THE CONTINENTAL SLOPE OF THE CEARÁ BASIN: AN INTEGRATED ANALYSIS BASED ON PLANKTIC FORAMINIFERA, SEDIMENTOLOGICAL AND GEOCHEMICAL ASPECTS
}

\author{
AGATHE ARRISSA NOUCOUCOUK (1) \\ Programa de Pós-Graduação em Geologia, Centro de Ciências, Universidade Federal do Ceará, \\ Av. Humberto Monte, s/n, Campus do Pici, 60455-760, Fortaleza, CE, Brazil. \\ noucoucouk@gmail.com
}

ROBBYSON MENDES MELO (D)

Laboratório de Micropaleontologia Aplicada (LMA/LAGESE/LITPEG), , Universidade Federal de Pernambuco, Av. da Arquitetura, s/n, Cidade Universitária, 50740-550, Recife, PE, Brazil.

robbysonmelo@gmail.com

\section{GEORGE SATANDER SÁ FREIRE}

Departamento de Geologia, , Centro de Ciências, Universidade Federal do Ceará, Av. Humberto Monte, s/n, Campus do Pici, 60455-760, Fortaleza, CE, Brazil. satanderfreire@gmail.com

\author{
ELDEMAR DE ALBUQUERQUE MENOR (D) \\ Departamento de Geologia, Universidade Federal de Pernambuco, Av. da Arquitetura, s/n, \\ Cidade Universitária, 50740-550, Recife, PE, Brazil. \\ eamenor@gmail.com
}

\begin{abstract}
This research addresses paleoclimatic variations using sedimentological, geochemical, and planktic foraminifera. The study was carried out in a survey core (ANP 1011) collected on the continental slope of the Icaraí Sub-basin (Ceará Basin), on the coast of the Municipality of Itapipoca, $\mathrm{CE}$, Brazil. Particle size analysis, $\mathrm{CaCO}_{3}$ content, $\mathrm{Ti} / \mathrm{Ca}$ and $\mathrm{Fe} / \mathrm{Ca}$ ratios, and the analysis of foraminifera associations for biostratigraphic purposes were performed. Based on the relative abundance of planktic foraminifera, with indicators of warm and cold water throughout the studied cores, two biozones (Y: Upper Pleistocene and Z: Holocene), and two subzones (Z2 and Z1) were recognized. The data of sedimentological markers obtained confirmed the occurrence of more wet phases in northeastern Brazil during the early stages of the Holocene. The $\mathrm{Ti} / \mathrm{Ca}$ and $\mathrm{Fe} / \mathrm{Ca}$ ratios, as well as the geochemical and micropaleontological proxies, indicated a farther north displacement of the Intertropical Convergence Zone (ITCZ) in the Pleistocene-Holocene transition. This may have caused greater precipitation in the Northeastern region of Brazil, effectuating the entry of a high volume of terrestrial sediments directly into the ocean basin.
\end{abstract}

Keywords: Quaternary biostratigraphy, marine sedimentation, ITCZ mobility, paleoclimate.

RESUMO - Esta pesquisa aborda as variações paleoclimáticas, utilizando foraminíferos planctônicos, marcadores sedimentológicos e geoquímicos. O estudo foi realizado em um testemunho de sondagem (ANP 1011) coletado no talude continental da Sub-bacia Icaraí (Bacia do Ceará), costa do Município de Itapipoca, CE. Foram realizadas análises granulométricas, teor de CaCO3, razões Ti/Ca e Fe/Ca e estudo das associações dos foraminíferos para fins bioestratigráficos. Com base nas abundâncias relativas de foraminíferos planctônicos indicadores de águas quentes e frias ao longo dos testemunhos estudados, foram reconhecidas duas biozonas (Y: Pleistoceno superior e Z: Holoceno) e duas subzonas (Z2 e Z1). Os dados de marcadores sedimentológicos obtidos confirmam a ocorrência de mais fases úmidas no Nordeste do Brasil durante o início do Holoceno. As razões dos elementos $\mathrm{Ti} / \mathrm{Ca}, \mathrm{Fe} / \mathrm{Ca}$, indicam, como os proxies geoquímicos e micropaleontológicos, um deslocamento mais ao norte da Zona de Convergência Intertropical (ZCIT) na transição Pleistoceno-Holoceno, provocando maior precipitação na região nordestino do Brasil com entrada de um volume alto de sedimentos terrígenos diretamente para a bacia oceânica.

Palavras-chave: bioestratigrafia do Quaternário, sedimentação marinha, mobilidade da ZCIT, paleoclima. 


\section{INTRODUCTION}

Due to the fact that oceanic processes have been playing a major role in climate change in the history of the earth, it is necessary to understand the variations that have occurred in the ocean during the past to be able to understand and predict future climate changes. This can be done through the study of marine sediments and microfossils. Climate change and its consequences are part of the Quaternary narrative, which comprises the last 2.6 million years of earth's history. During the Pleistocene-Holocene, one of the most significant episodes of paleoclimatic change occurred in the last 20,000 years, marked by repeated cycles of glacial advance and retreat, which directly affected the terrestrial and aquatic biota (Arz et al., 1999; Bradley, 2015). Geochemical data indicated that during the Last Glacial Maximum, the circulation of North Atlantic Deep Water (NADW) has become slower (Burns \& Maslin, 1999).

Fluctuations in the formation of North Atlantic Deep Water at millennial-scale are related to the Heinrich, Dansgaard-Oeschger and Younger Dryas events (Maslin, 1995; Maslin et al., 2001; Elliot et al., 2002). These events are related to fluctuations in the Intertropical Convergence Zone (ITCZ) (Arz et al., 1998; 1999; Cruz et al., 2006; Wang et $a l ., 2007)$, in addition to changes in the monsoon systems of South America and Asia (Cheng et al., 2009), and fluctuations in the Atlantic Meridional Overturn Circulation (AMOC) (Mcmanus et al., 2004; Weldeab et al., 2006).

In general, Heinrich stadial are characterized by the presence of massive layers of ice-rafted debris in the North Atlantic (Heinrich, 1988; Bond et al., 1992). Heinrich stages, probably involves weakening in the strength of the AMOC (Clark et al., 2002; Henry et al., 2016). Such weakness in AMOC strength had a fundamental role in regulating millennial-scale tropical climate (Voelker, 2002) and influenced the ITCZ, consequently influencing precipitation over tropical South America. For a highly weakened AMOC during Heinrich stage, numerous studies demonstrated an increase in precipitation over northeastern Brazil (Arz et al., 1998; Wang et al., 2005; Jaeschke et al., 2007) and a decrease over northernmost South America (Peterson et al., 2000; Deplazes et al., 2013).

Records of climatic events occurring on the planet are preserved in sediments and, with the help of sedimentological, geochemical and micropaleontological markers, it is possible to obtain information about the geological, chemical, and biological processes, allowing the evaluation of changes in marine productivity and terrestrial contributions (Killops \& Killops, 2005; Bradley, 2015). Elements such as iron (Fe), titanium (Ti), and calcium $(\mathrm{Ca})$ are important tools in paleoceanographic and paleoclimatic studies. According to Bradley (2015), variations in the concentration of these geochemical markers over time are indicative of the climate conditions. In addition, $\mathrm{Fe} / \mathrm{Ca}$ and $\mathrm{Ti} / \mathrm{Ca}$ ratios can be used to track changes in continental inputs of mainly fluvial origin (Arz et al., 1998; 1999; Jaeschke et al., 2007).

As constituents of biogenic sediments, foraminifera (protists with pseudoreticulopods) are sensitive to environmental changes, both by biotic (food availability, interspecific competition) and abiotic (temperature, salinity, turbidity, nutrients, oxygen, substrate type) factors (Sen Gupta, 1999). The knowledge of the ecological behavior of planktic foraminifera in particular makes this group an important tool for determining the relative age of sedimentary rock layers. The work of Ericson \& Wollin (1968), based on the appearance and disappearance of the Globorotalia menardii plexus ( $G$. menardii, G. tumida, $G$. flexuosa, and G. fimbriata) consists of the biozoning of reference for the Atlantic Ocean Quaternary. The intervals where the G. menardii plexus is present are considered interglacial and its absence identifies the glacial intervals. Vicalvi (1997, 2013), proposed the ecostratigraphic slicing of the section for the Brazilian southeast continental margin. The percentage variation of the G. menardii plexus in relation to the total fauna of planktic foraminifera, in addition to the presence or absence of the Pulleniatina plexus (P. primalis, P. obliquiloculata, and $P$. finalis), enabled the refinement of Quaternary biostratigraphy. However, Costa et al. (2018) suggested that the typical cyclic disappearances and 
reappearances of the menardiform foraminifera do not occur synchronously throughout the Atlantic Ocean and, therefore, should not be employed for paleoclimatic zonation.

For the part, in the equatorial margin of northeast Brazil few studies were developed (Vicalvi \& Palma, 1980; Vilela \& Maslin, 1997; Wilson et al., 2019). Biostratigraphic studies based on foraminifera in the Quaternary section of the continental slope of the Ceará Basin are scarce, which has made it difficult to better understand the geochronology of events that have occurred in the last 20,000 years. In this way, the objective of this work is to characterize the Upper Pleistocene-Holocene interval in the continental slope of the Ceará Basin, using sedimentological, geochemical, and planktic foraminifera to understand the paleoceanographic and paleoclimatic variations that occurred in this region.

\section{STUDY AREA}

The studied area is located in the Icaraí Subbasin, which forms the eastern portion of the Ceará Basin (Costa et al., 1990), Ceará (CE), on the continental equatorial margin of northeast Brazil (Figure 1).

The area is directly influenced by the North Brazilian Current (NBC), the North Equatorial SubCurrent (NESC), the North Equatorial CounterCurrent (NECC), and the North Equatorial Current (NEC) (Silveira et al., 2004). The NBC formation is related to a bifurcation in the northern direction of the southern branch of the South Equatorial Current (SEC) when it reaches the Brazilian continental margin between latitudes $10^{\circ} \mathrm{S}$ and $15^{\circ} \mathrm{S}$ (Schott et al., 2004; Talley et al., 2011). The NBC is known to be the largest surface flow component of the Southern Atlantic Overturning Circulation

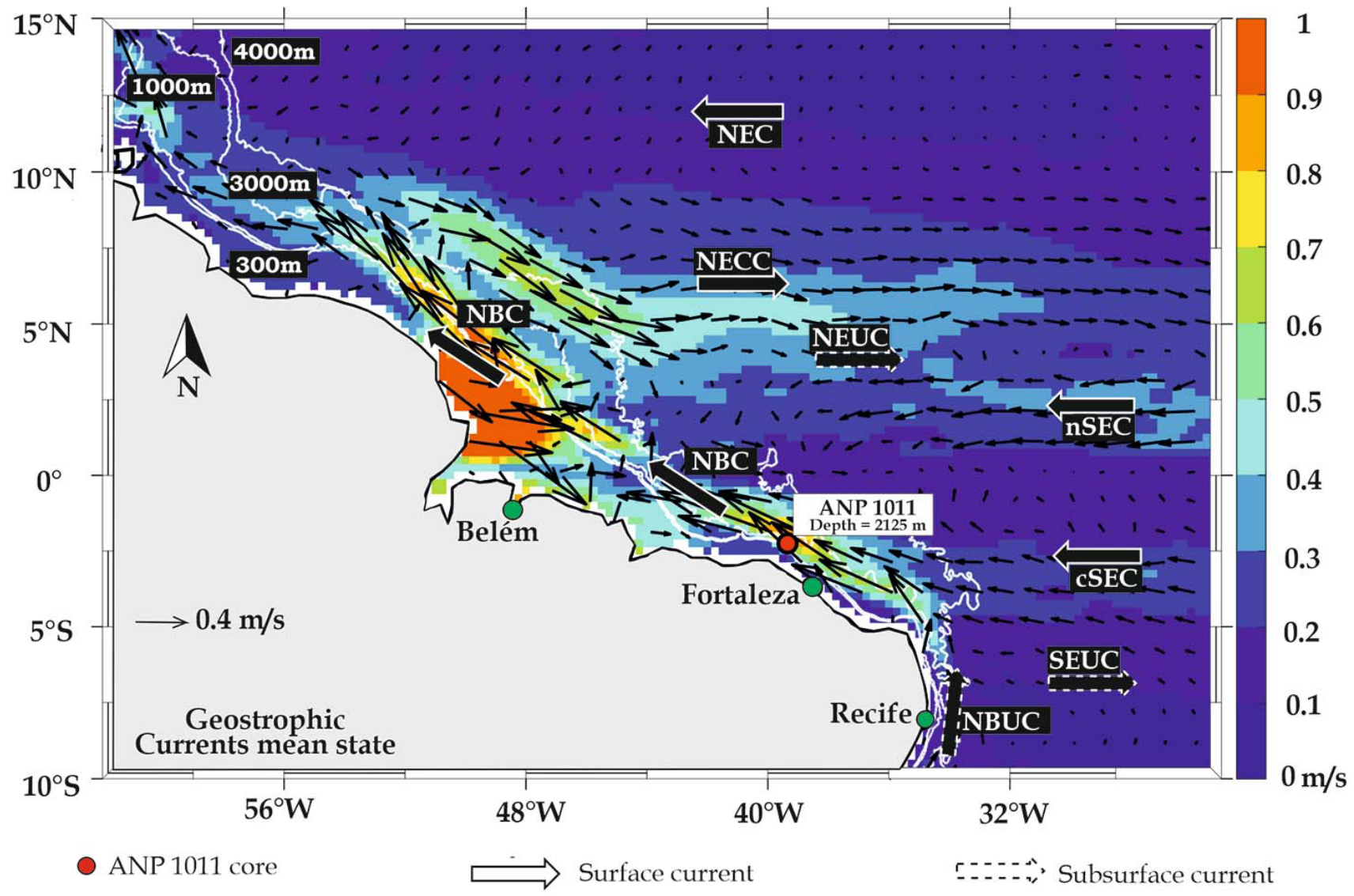
NBC $=$ North Brazilian Current
NEC $=$ North Equatorial Current
cSEC $=$ Center branch of the South Equatorial Current
NECC $=$ North Equatorial Counter-Current
nSEC $=$ Northern branch of the South Equatorial Current
SEUC $=$ South Equatorial Undercurrents
NEUC $=$ North Equatorial Undercurrents
NBUC $=$ North Brazilian Undercurrents

Figure 1. Location map of the ANP 1011 core on the Ceará Basin showing the surface circulation in the Brazilian Equatorial Margin, the physiography of the study area and current arrows are superimposed on their speed. 
(AMOC); through the northward surface water transport and the inter-hemispheric oceanic heat exchange, it acts as a link between the northern and southern hemispheres and plays an important role in the equatorial counter-zonal current system and the global climate (Zhang et al., 2011).

The mobility of NBC transport in the uppermost $800 \mathrm{~m}$ of the water column at $4^{\circ} \mathrm{N}$ shows an annual average of $26 \mathrm{~Sv}$ with highs of $36 \mathrm{~Sv}$ between July and August and lows of $13 \mathrm{~Sv}$ between April and May. This mobility coincides with the change in transport on the ocean surface associated with changes in wind shear present in the tropical Atlantic and with the seasonal migration of the ITCZ (Johns et al., 1998). According to Zhang et al. (2011), NBC presents multidecadal variability, with response of some years of delay, in relation to the thickness of the water layer of the deep Labrador Sea convection region, the formation region of the NADW body, suggesting the mobility of NBC transport as an indicator of AMOC variability.

\section{MATERIAL AND METHODS}

Analyses were performed on 15 samples collected from a piston core. The ANP 1011 core, $151.5 \mathrm{~cm}$ long, was collected by the ship Fugro Odissey in the campaign between June 30 and July 21, 2011, between coordinates $2^{\circ} 13^{\prime} 03^{\prime \prime} \mathrm{S} / 39^{\circ} 23^{\prime} 22^{\prime \prime} \mathrm{E}$, at a depth of $2125 \mathrm{~m}$, between coordinates $2^{\circ} 13^{\prime} 03$ ' $\mathrm{S} / 39^{\circ} 23^{\prime} 22^{\prime \prime} \mathrm{E}$, at a depth of $2125 \mathrm{~m}$, to NW from Fortaleza, CE (Figure 1).

In sedimentological analyzes, a macroscopic and granulometric description was performed using the Rock-Color Chart, from the Munsell Chart. Variations in the levels of calcium carbonate $\left(\mathrm{CaCO}_{3}\right)$ and the ratios between the elements $\mathrm{Ti}, \mathrm{Fe}$, and $\mathrm{Ca}$ in the fine fractions were used as continental climate indicators.

In the granulometric analysis, the samples were washed with running water over a sieve with $0.062 \mathrm{~mm}$ opening mesh. The mud fractions were collected in a container and left to rest for a period of 48 hours to decant, being subsequently taken to the oven $\left(60^{\circ} \mathrm{C}\right)$. The material retained in the $0.062 \mathrm{~mm}$ sieve was also taken to the oven $\left(60^{\circ} \mathrm{C}\right)$ and, after drying, dry sieving was carried out in a ROT-AP type system, using a set of sieves ranging from $4 \mathrm{~mm}$ to
$0.062 \mathrm{~mm}$. The material retained in each sieve was collected and weighed for percentage calculations, including the gravel fraction (grains with diameter $>2 \mathrm{~mm}$ ), the sand fraction (2 to $0.062 \mathrm{~mm}$ ) and the mud fraction (silt $0.032 \mathrm{~mm}$ and clay $0.002 \mathrm{~mm}$ ).

The process carried out to determine the carbonate content present in the samples, occurred from the digestion in hydrochloric acid $(\mathrm{HCl})$, with the sample being washed and weighed. In this method, approximately $0.5 \mathrm{~g}$ of each sample was placed in a conical flask and weighed on an analytical scale. About $10 \mathrm{ml}$ of $\mathrm{HCl}$ were added. The conical flask was stirred periodically over 24 hours. Then, the supernatant was removed and the decarbonated sample is washed with distilled water to remove $\mathrm{HCl}$ residues. After the sample, it was oven dried at $60^{\circ} \mathrm{C}$ and again weighed. Finally, the calcium carbonate content in the sample was calculated through the difference in weight before and after decarbonation.

For the fluorescence method used to identify the chemical elements of the clay fraction, a ZSX Mini II X-ray fluorescence spectrometer model Phillips PW 2510 was utilized, which consists of the analysis of molten tablets from the ground sample with a mixture of tetra and metaborate of lithium. To quantify terrestrial sedimentation, the $\mathrm{XRF}$ ratios of $\mathrm{Ti} / \mathrm{Ca}$ and $\mathrm{Fe} / \mathrm{Ca}$ were used.

Micropaleontological preparation followed the conventional methodology of washing the sediment in water and drying. After dry sieving, each sediment sample retained in the $0.150 \mathrm{~mm}$ sieve was split, with about 300 foraminiferal tests collected and classified according to specialized bibliographies. The main species was photographed using a scanning electron microscope. In addition, specific richness data were obtained on basis of the relationship between the total number of species (NS) and the total number of individuals (TNI) present in each sample $(\mathrm{R}=$ (NS-1)/logTNI). Moreover, the planktic/benthic ratio was calculated using:

$$
\mathrm{P} / \mathrm{B}=(\mathrm{P} / \mathrm{F}) \times 100
$$

where $\mathrm{P}=$ total number of planktic specimens; $\mathrm{B}=$ total number of benthic specimens and $\mathrm{F}=$ total number of foraminifera. Relative abundance $(\mathrm{RA}=(\mathrm{N} \times 100) / \mathrm{T})$, is the ratio of the number of individuals of a given species in the sample $(\mathbf{N})$ and the total number of individuals of all species in the 
sample (T). The criteria adopted were according to Dajoz (1983): trace species (abundance less than 1\%); accidental species (abundance between $1 \%-5 \%$ ); main species (abundance greater than 5\%). To delimit the biozones of the studied section, the disappearances and reappearances of marker species were taken into account, following the works of Ericson \& Wollin (1968) and Vicalvi (1997, 2013).

\section{RESULTS}

\section{Sedimentological and geochemical aspects}

The core has a homogeneous structure in its entire length and is composed of mud (Figure 2). Throughout the core, a mixture of fragmented and well-preserved tests of foraminifera, pteropods, gastropods, ostracods, bryozoan, brachiopods, and spines of echinoids were observed. Biodetrites were observed between $65-66 \mathrm{~cm}$ and at the $76 \mathrm{~cm}$ level. Bioturbation was seen between 100-106 cm.

Regarding the granulometric analysis, the average of gravel contents was $0.14 \%$ (range 0.0 $0.45 \%$ ), representing $<1 \%$ of the sediment in the core. The whole gravel fraction present is essentially composed of biotic organisms. The average sand content is $15.04 \%$ (range $6.13-24.17 \%$ ), with the largest value at the top of the core. The average mud content was $84.82 \%$ (range 75.59-93.79\%), where the highest of these values was recorded in sample 79-82 cm (Figure 2).

Regarding $\mathrm{CaCO}_{3}$ content, an average percentage of 53.14\% was found (range 27.06\%- 62.87\%); sample $0-6 \mathrm{~cm}$ presented the lowest $\mathrm{CaCO}_{3}$ content (Figure 2), comprise siliciclastic sediment, which was classified as terrestrial mud due to its $\mathrm{CaCO}_{3}$ content

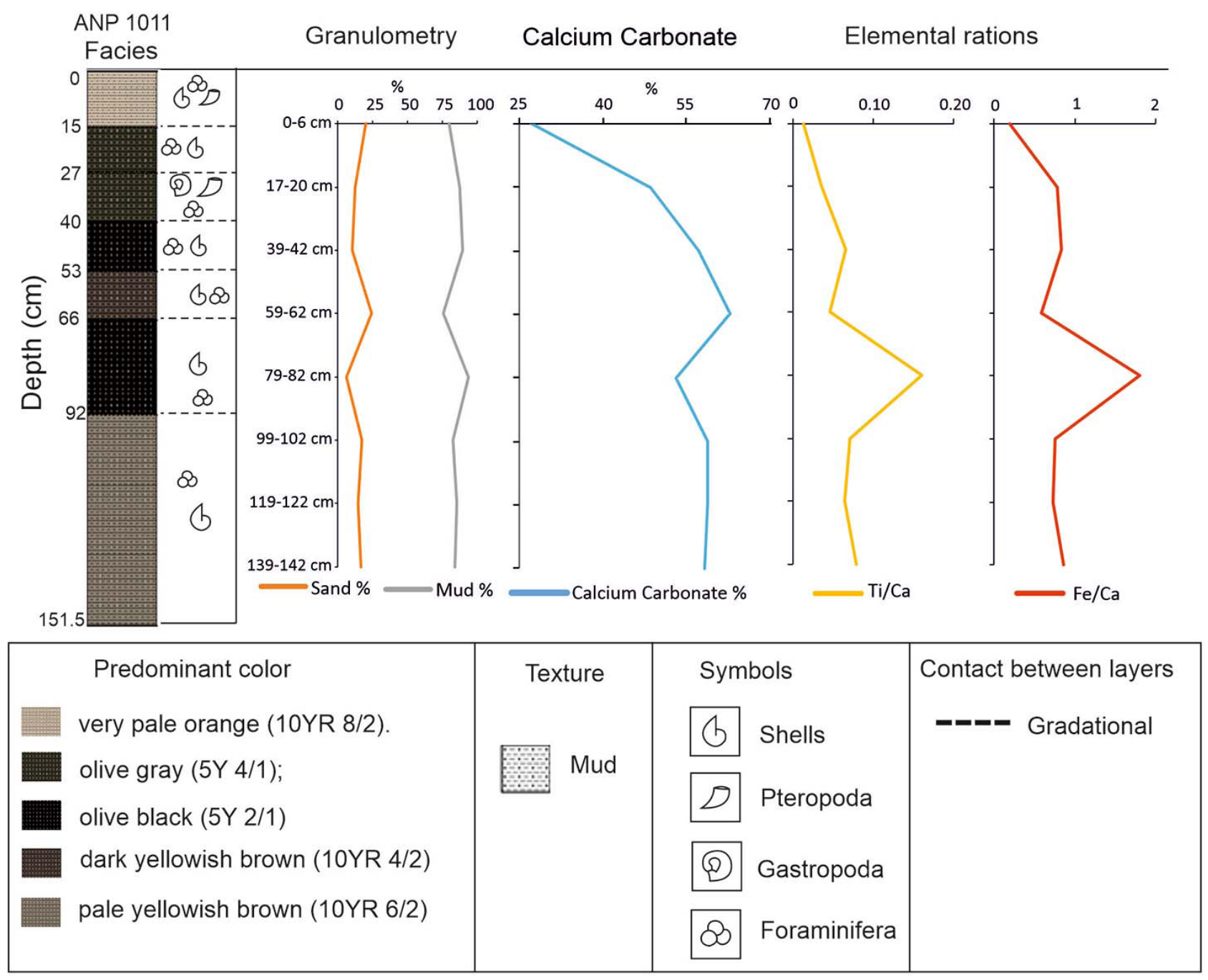

Figure 2. Lithological profile, particle size fractions, calcium carbonate, and elementary ratios of the ANP 1011 core. 
less than $30 \%$ and mud content above $15 \%$. The $17-20 \mathrm{~cm}$ sample are composed of silicibioclastic sediment, which was classified as sandy loam due to its $\mathrm{CaCO}_{3}$ content between 30 a $50 \%$ and mud content above $15 \%$. The other samples of the core comprise biosiliciclastic sediment, having been classified as calcareous marl, as they have a $\mathrm{CaCO}_{3}$ content between $50-70 \%$ and mud content above $15 \%$.

Regarding the element ratios analyzed in the ANP 1011 core (Figure 2), Ti/Ca and Fe/Ca presented similar behaviors. The values were relatively constant in the range between 139-142 cm to $99-102 \mathrm{~cm}$, while in sample $79-82 \mathrm{~cm}$ the values increased (Ti/Ca: $0.16 ; \mathrm{Fe} / \mathrm{Ca}: 1.8)$, followed by a drop in the sample 59-62 cm (Ti/Ca: 0.05; Fe/Ca: $0.58)$. The lowest values are found in sample $0-6$ cm (Ti/Ca: 0.01; Fe/Ca: 0.19).

\section{Association of foraminifera}

In the 15 samples of the ANP 1011 core, 5698 specimens of foraminifera were recovered with well-preserved tests predominantly white. Of this total, 5611 are planktic foraminifera divided into 27 taxa (Appendix 1) and 87 are benthic foraminifera. The main species are illustrated in Figures 3 and 4. It was possible to recognize 153 foraminifera tests affected by some type of taphonomic process, whether fragmentation, dissolution, bioerosion or incrustation.

The $\mathrm{P} / \mathrm{B}$ ratio showed an average of 96.81 , (minimum 90.42, maximum 99.13). There was a significant decrease in sample $67-70 \mathrm{~cm}$, reaching 90.42 (Figure 5). The calculations of the number of species (NS) and richness (R) were made only on the basis of planktic foraminifera. The highest NS

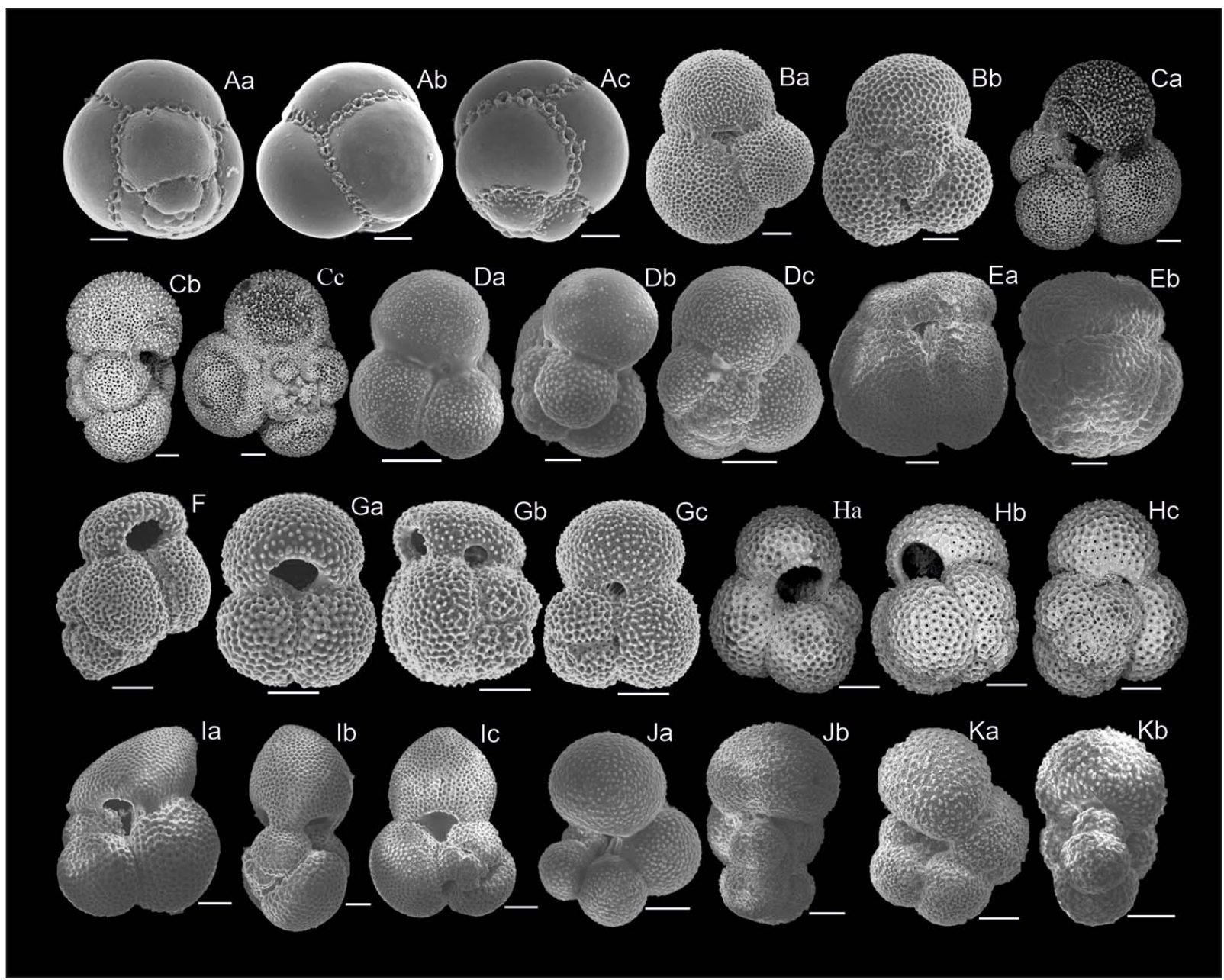

Figure 3. Planktic foraminifera of the ANP 1011 core: Aa-Ac, Candeina nitida: a, umbilical view; b, side view; c, spiral view; Ba-Bb, Globigerinita glutinata: a, umbilical view; b, spiral view; Ca-Cc, Globigerina bulloides: a, umbilical view; b, side view; c, spiral view; Da-Dc, Globigerinita sp.: a, umbilical view; b, side view; c, spiral view; Ea-Eb, Globigerinoides conglobatus: a, umbilical view; b, side view; F, Globigerinoides ruber form pyramidalis: Ga-Gc, Globigerinoides ruber: a, umbilical view; b, side view; c, spiral view; Ha-Hc, Globoturborotalita rubescens: a, umbilical view; b, side view; c, spiral view; Ia-Ic, Trilobatus sacculifer: a, umbilical view; b, side view; c, spiral view; Ja-Jb, Globigerinella calida: a, umbilical view; b, side view; Ka-Kb, Globigerinella siphonifera: a, umbilical view; b, side view. Scale bars $=100 \mu \mathrm{m}$. 
was found in samples $99-102 \mathrm{~cm}, 87-90 \mathrm{~cm}$, and $79-82 \mathrm{~cm}$, with 19 species. The lowest NS occurred in sample $47-50 \mathrm{~cm}$, with 13 species (Figure 5). The richness has the highest value found in sample 99-102 cm, with $\mathrm{R}=7.36$. The lowest richness is found in sample $47-50 \mathrm{~cm}$, with $\mathrm{R}=4.67$ (Figure 5).

Along the core, five main species were identified (Figure 6): Globigerinoides ruber white (44.73\%), Trilobatus trilobus (8.26\%), Globigerinoides ruber pink (7.31\%), Neogloboquadrina dutertrei (6.79\%), Trilobatus sacculifer (6.01\%). Eight accidental species were found (Figure 6): Globigerina bulloides (4.12\%), Globigerinella siphonifera (3.53\%), Globigerinella calida (3.28\%), Globorotalia truncatulinoides (3.22\%), Globigerinoides elongata (2.98\%), Globorotalia menardii (2.18\%), Pulleniatina obliquiloculata $(1.63 \%)$ and Globorotalia tumida $(1.19 \%)$.

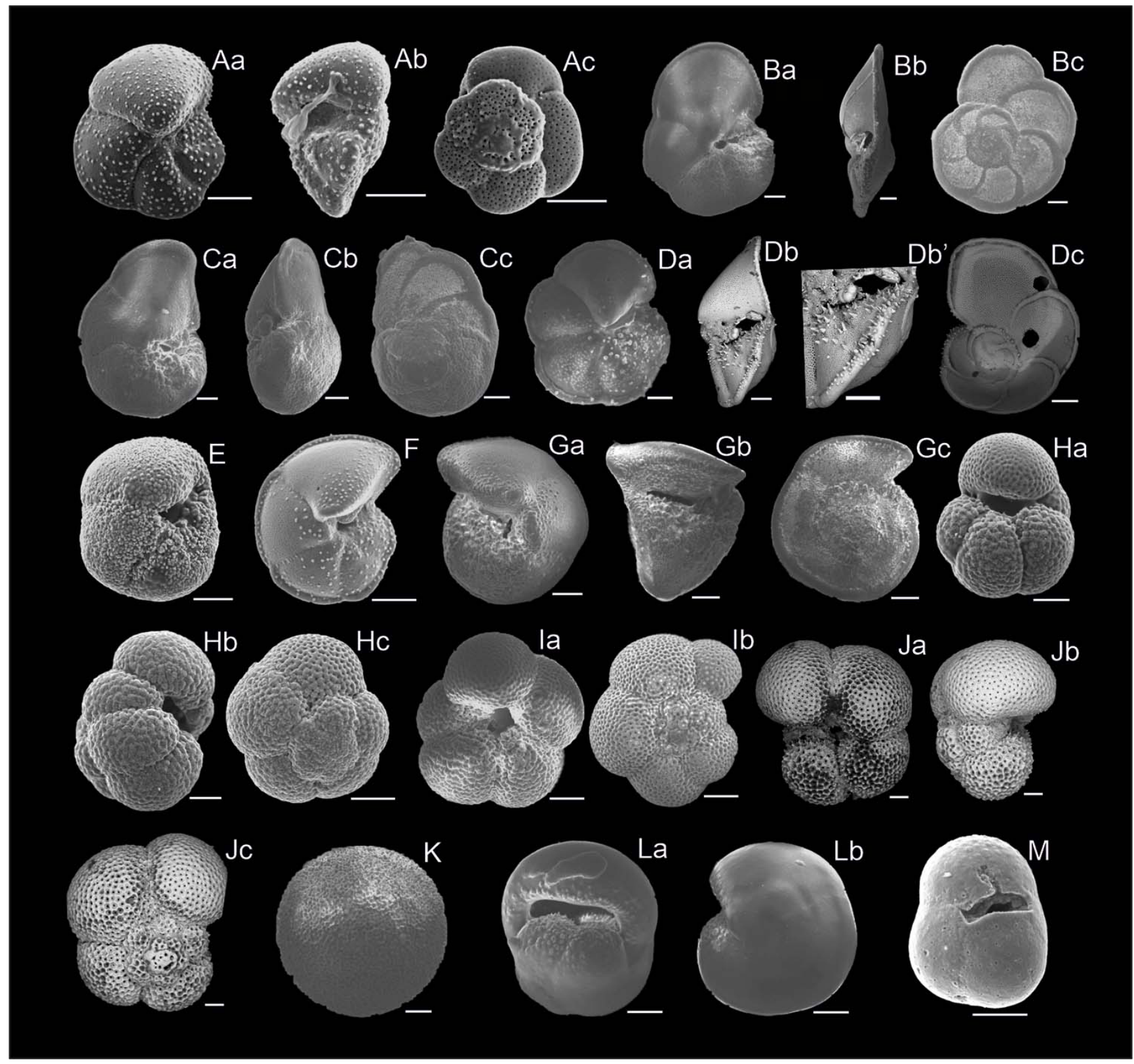

Figure 4. Planktic foraminifera of the ANP 1011 core: Aa-Ac, Globorotalia crassaformis viola: a, umbilical view; b, side view; c, spiral view; Ba-Bc, Globorotalia menardii: a, umbilical view; b, side view; c, spiral view; Ca-Cc, Globorotalia tumida: a, umbilical view; b, side view; c, spiral view; Da-Dc, Globorotalia aff. fimbriata: a, umbilical view; b, side view; c, spiral view; E, Globoconella inflata; F, Globorotalia truncatulinoides excelsa; Ga-Gc, Globorotalia truncatulinoides truncatulinoides: a, umbilical view; b, side view; c, spiral view; Ha-Hc, Neogloboquadrina dutertrei: a, umbilical view; b, side view; c, spiral view; Ia-Ib, Neogloboquadrina dutertrei: a, umbilical view; b, spiral view; Ja-Jc, Neogloboquadrina incompta: a, umbilical view; b, side view; c, spiral view; K, Orbulina universa; La-Lb, Pulleniatina obliquiloculata: a, umbilical view; b, side view; M, Sphaeroidinellopsis sp. Scale bars $=100 \mu m$. 


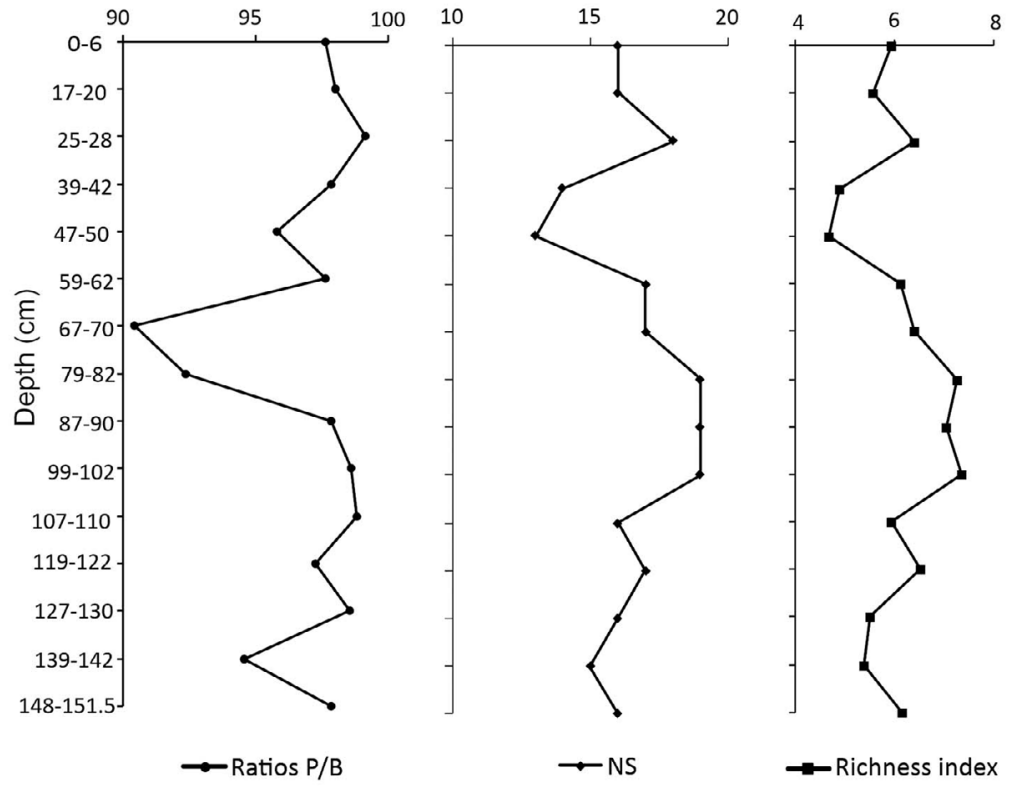

Figure 5. A, Planktic/Benthic Ratio (P/B): B, Number of Species (NS) and $\mathbf{C}$, Richness index (R) in the ANP 1011 core.
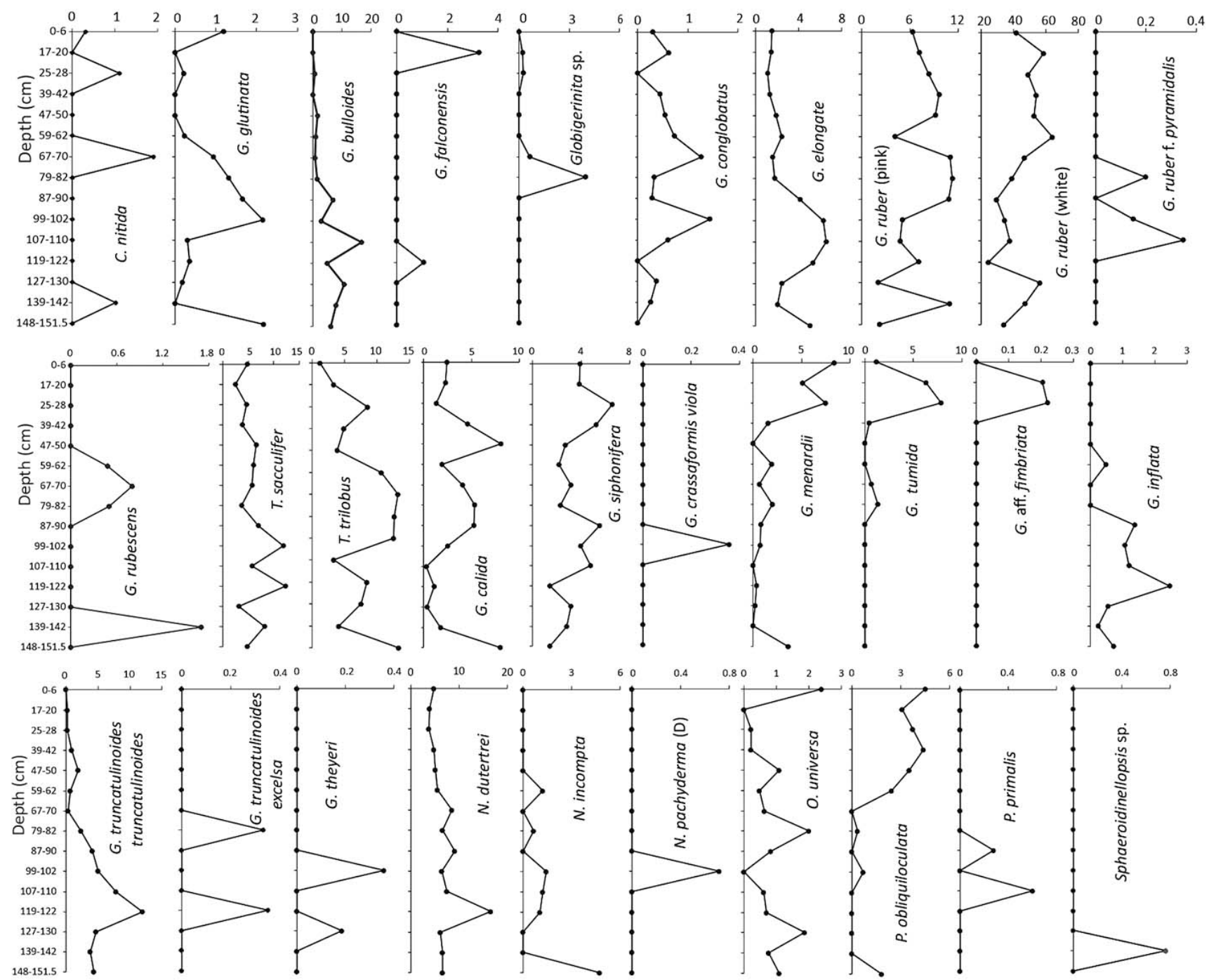

Figure 6. Distribution of the relative abundance of planktic foraminifera species along with the ANP 1011 core. 


\section{Biostratigraphy}

The climate zoning established for the area was based on the work of Ericson \& Wollin (1968) and Vicalvi (1997, 2013). Based on the relative abundances of planktic foraminifera that are indicators of warm (Globorotalia menardii and G. tumida) and cool water (Globoconella inflata and G. truncatulinoides), along with the studied cores, the following biozones were recognized (Figure 7): Biozone Y, which characterizes the Upper Pleistocene; and Biozone Z (Z2 and Z1 sub-zones), which is Holocene. The interval that extends from the base of the core $(151.5 \mathrm{~cm})$ to the sample $79-82 \mathrm{~cm}$ was identified as belonging to the Pleistocene Biozone Y (glacial), evidenced by a reduction in the percentage values of the presence of $G$. menardii, absence of $G$. tumida and presence of cool-water species such as G. truncatulinoides $(11.97 \%$ to $3.81 \%)$ and $G$. inflata $(2.46 \%$ to $0.25 \%$ ).

The presence of Globorotalia menardii plexus (up to 13.96\%) and Pulleniatina obliquiloculata (up to $4.49 \%$ ) between the sample $79-82 \mathrm{~cm}$ and the top of the core characterizes the Biozone $\mathrm{Z}$ (Holocene).
The species G. truncatulinoides and Globoconella inflata were practically absent in the Holocene. It was possible to identify subzones $\mathrm{Z} 2$ and $\mathrm{Z1}$ based on the percentages of $G$. menardii along the Biozone Z. Thus, Z2 subzone was identified from sample 79-82 cm to sample $25-28 \mathrm{~cm}$, with a mean relative abundance of $G$. menardii plexus $(1.7 \%)$, while the $\mathrm{Z} 1$ subzone was identified between sample 25-28 cm and the top, where G. menardii plexus presented an average relative abundance of $12.26 \%$ (6.98\% of G. menardii, $5.14 \%$ of $G$. tumida and $0.14 \%$ of $G$. aff. fimbriata). The sedimentation rate of Biozone $Z$ was estimated at $7.45 \mathrm{~cm} / \mathrm{ka}$.

\section{DISCUSSION}

The studied section of the ANP 1011 core sample is composed of siliciclastic, silicibioclastic and biosiliciclastic sediments and has mud textural facies (Shepard, 1954; Vital et al., 2005). The high deposition of finer sediments (mud) suggests a low intensity hydrodynamic regime, which may indicate stable oceanographic conditions (Nagai et al., 2009).

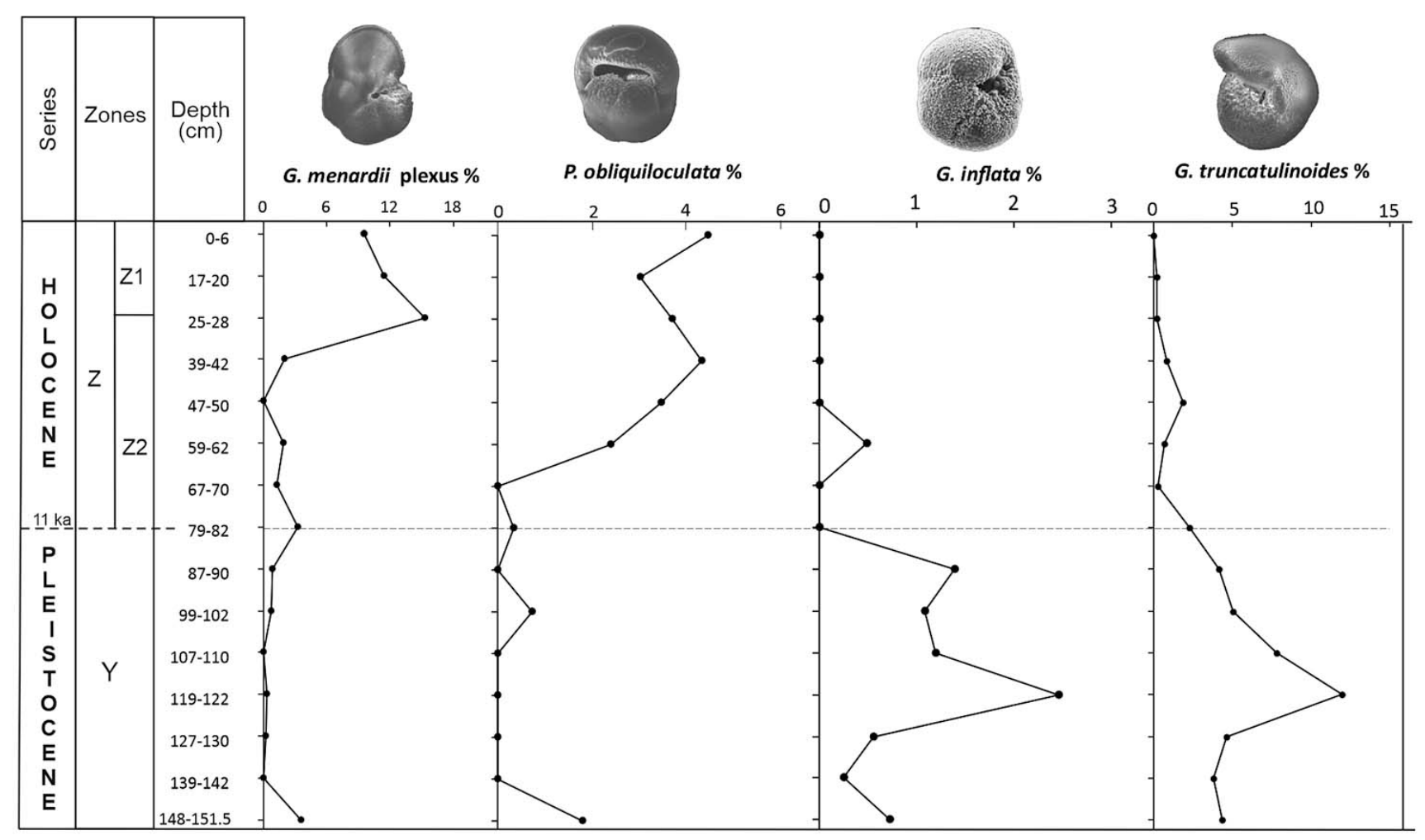

Figure 7. Section biozoning (ANP 1011 core) based on planktic foraminifera. The time scale was based on Vicalvi (1997, 2013). 


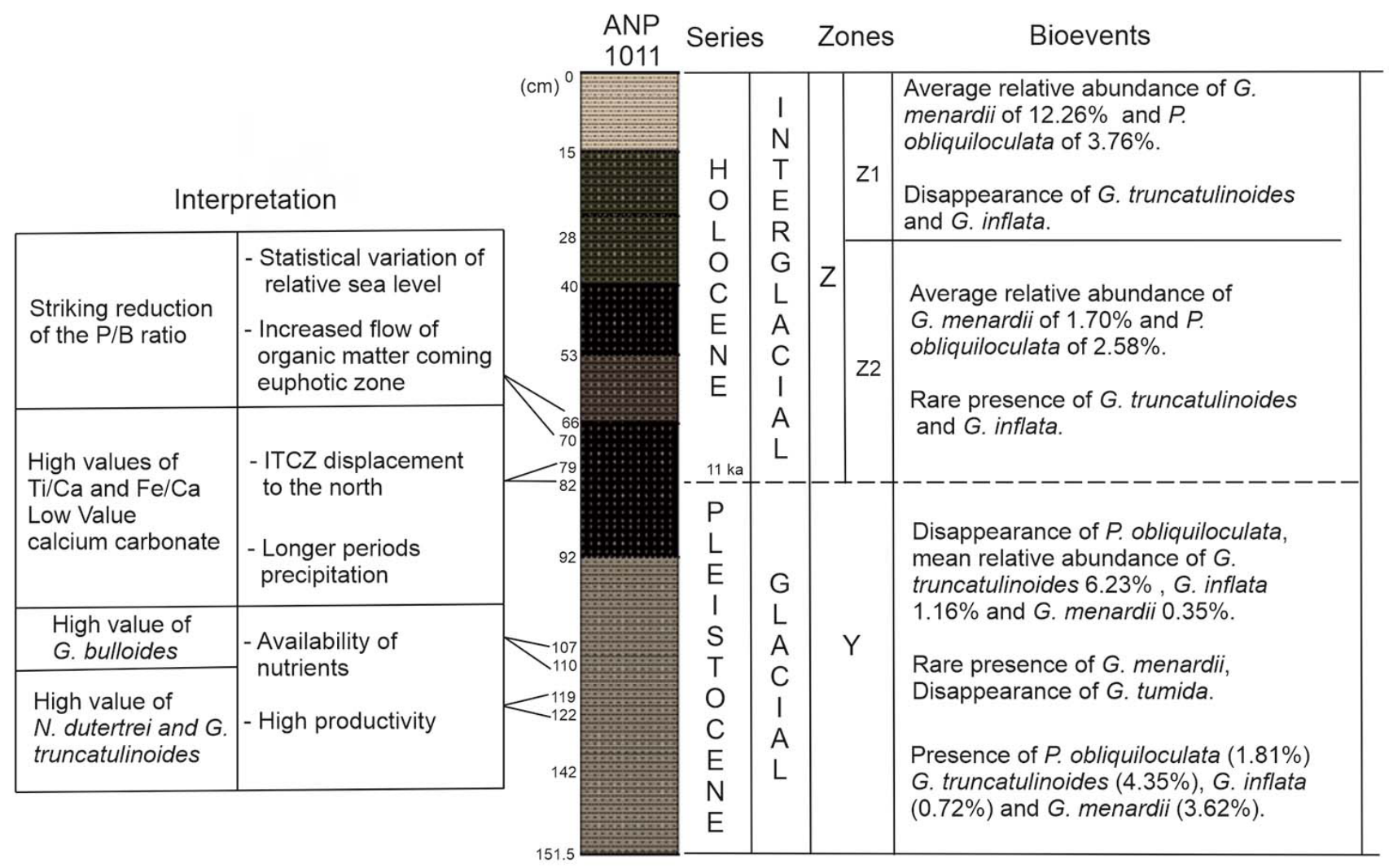

Figure 8. Integration and interpretation of data in the ANP 1011 core.

The studied section covers strata of Pleistocene (Biozone Y)-Holocene (Biozone Z) age determined from the planktic foraminifera associations (Figure 8), where Globigerinoides ruber white, indicator of warm water bodies (Boltovskoy, 1959), occurs predominantly in all samples. The Biozone $\mathrm{Y}$ in the studied section is characterized by high levels of Globigerina bulloides, Neogloboquadrina dutertrei, and Globorotalia truncatulinoides (Figure 8), associated with high productivity and greater availability of nutrients (Hilbrecht, 1997). The $G$. bulloides of reduced size has its greatest representation in the glacial period (Biozone Y). This species was found the continental margin of the states of Alagoas and Sergipe (Tinoco, 1980), as well as on the middle platform and delta front slope of the Amazon River (Vilela \& Maslin, 1997). The abundance of this eurythermal species (Boltovskoy, 1970) in the analyzed core is indicative of the availability of nutrients in the studied area during this time interval, indicating a high productivity environment (Hilbrecht, 1997). The species Trilobatus trilobus was registered by Tinoco
(1985) as the most frequent taxon in the superficial sediments of the platform and the continental slope in the limits of the North-Northeast Brazilian Subprovince.

At the base of the section, related to sample 148-151.5 cm, the presence of Pulleniatina obliquiloculata was identified, characterizing periods when the ocean waters of the region were less cold (Figure 8), as observed in core samples from the Campos Basin, southeastern region of the Brazilian coast (Vicalvi, 1997, 2013). In this interval (Biozone Y), higher relative abundances of Globorotalia truncatulinoides and Neogloboquadrina dutertrei are observed in sample 119-122 cm, while high values of Globigerina bulloides occur in sample $107-110 \mathrm{~cm}$. In the case of G. truncatulinoides, higher values of abundance have been used as an indicator of vertical mixing of surface waters (Toledo et al., 2007). According to Hemleben et al. (1989), G. truncatulinoides inhabits greater depths at low latitudes, except at the beginning of the southern spring, when it ascends through the water column as part of its reproductive cycle, 
descending again during the summer and autumn. In turn, the abundance of $N$. dutertrei is related both to the euphotic zone, and to the rise and fall of the thermocline (Bé et al., 1985), or even, it is favored by low salinities (Cullen, 1981). In the latter case, its abundance may reflect the presence of a more fertile and less saline water mass, while low salinities are associated with increased water temperature.

The total or partial disappearance of Pulleniatina obliquiloculata in the interval $142-79 \mathrm{~cm}$, can characterize the subzone Y1. The disappearance and reappearance of $P$. obliquiloculata in the last 175,000 years is an important datum for correlations (Vicalvi \& Palma, 1980). Ericson \& Wollin (1968) noted that $P$. obliquiloculata disappears in the middle of the Biozone Y and Damuth (1973) reported this disappearance in 40,000 years BP and its reappearance occurs near the boundary between biozones $\mathrm{Y}$ and $\mathrm{Z}$ and remains abundant until the present.

The Holocene (Biozone Z) in the section studied is marked by a drop of the $\mathrm{P} / \mathrm{B}$ ratio, the presence of Globorotalia menardii plexus (up to $13.96 \%$ ) and Pulleniatina obliquiloculata (up to $4.49 \%$ ), and the disappearance of Globoconella inflata. We assigned the age of $11 \mathrm{ka}$ in the transition Pleistocene/ Holocene basis on the works of (Ericson \& Wollin, 1968; Vicalvi, 1997, 2013). However, Costa et al. (2018) observed an age of $9.7 \mathrm{ka}$ to that limit in the Santos Basin and believed that the difference of $2 \mathrm{ka}$ between the Santos Basin and the tropical Atlantic could be even greater. The disappearances and reappearances of the $G$. menardii plexus in the Atlantic Ocean are not synchronous (Pivel et al., 2013; Broecker \& Pena, 2014; Costa et al., 2018).

The increase in the amount of terrigenous material (non-carbonated material) in the studied area during the Pleistocene-Holocene transition (sample 79-82 cm) is reflected in the low $\mathrm{CaCO}_{3}$ value (Figure 8). In the Atlantic Ocean, the carbonate content of the seabed sediments during the interglacial periods is higher than during the glacial periods. This differs from what occurs in the Indian and Pacific Ocean (Volat et al., 1980; Hodell et al., 2001). Explanations for these differences in time and place have been the subject of extensive discussion (Suess, 1956; Volat et al., 1980). The main factors that led to this variability were the rate of production of calcium carbonate in relation to organic matter, the state of saturation of deepsea water, and the rate of entry of non-carbonated material. In the Atlantic Ocean, it is established that the production of calcium carbonate by coccoliths and foraminifera was greater during interglacial times and the clay intake was two to five times greater during glacial times (Bacon, 1984). The decrease in carbonate content and $\mathrm{Ti} / \mathrm{Ca}$ and $\mathrm{Fe} /$ $\mathrm{Ca}$ in the uppermost sample may be related to fragmented tests of foraminifera and characterize a dissolution process (Conan et al., 2002).

At the base of the Z2 subzone (depth 67-70 $\mathrm{cm}$ ), the reduction in $\mathrm{P} / \mathrm{B}$ ratio may suggest a response to the increase in the flow of organic matter of the euphotic zone (Lutze \& Coulbourn, 1983). According to Hemleben et al. (1989), the $\mathrm{P} / \mathrm{B}$ ratio is a reflection of the degree of influence of the neritic versus oceanic habitat at the time of deposition, and an average $\mathrm{P} / \mathrm{B}$ ratio above 90\% (a high $\mathrm{P} / \mathrm{B}$ ratio) indicates increase in depth and a longer distance from the coast (Murray $\&$ Alve, 2002). This phenomenon corroborates the classification of the studied area as a lower continental slope (Culver, 1988). In the study of the ANP 1011 core, variations in the $\mathrm{P} / \mathrm{B}$ ratio were found where no correlation with changes in paleobathymetry or paleoenvironment was possible. This suggests that depth cannot be the only factor responsible for all variations observed in the distribution of foraminiferal assemblages. Therefore, factors such as water bodies, inflows of terrestrial mud, redeposition, distance from the coast, and availability of nutrients (supply of organic matter) influence the distribution of these organisms on the continental slope.

The high values of $\mathrm{Ti} / \mathrm{Ca}$ and $\mathrm{Fe} / \mathrm{Ca}$ found in this work at the beginning of the Holocene (Figure 8) are related to an increase in continental drainage, showing periods of greater precipitation in the northeast region of Brazil as a consequence of the displacement of the ITCZ to the north (Zhang et al., 2017). Ca is an element related to the marine biogenic productivity of the continental shelf; therefore, it is associated with marine influence (Razik et al., 2013). While the Ti and Fe supplied from the hydrographic basin of the adjacent region are associated with terrigenous components (Nagai 
et al., 2009). The episodic increase in terrestrial markers may have been caused by climate change in coastal areas in northeastern Brazil (Rao et al., 1993; Arz et al., 1998, 1999; Jaeschke et al., 2007), as well as data from tributaries in the Amazon (Bouchez et al., 2011) that also indicate a clear inverse relationship between $\mathrm{Ti} / \mathrm{Ca}, \mathrm{Fe} / \mathrm{Ca}$ ratios and the continental contribution to the ocean basin. Slightly wetter and higher precipitation rates in the hydrographic basins of coastal rivers would increase soil erosion and runoff from rivers, and thus increase the supply of terrestrial sediments to the upper continental slope (Arz et al., 1998). Consequently, climate change in northeastern Brazil at the beginning of the Holocene has been related to the displacement of the Intertropical Convergence Zone to the north (Arz et al., 1998, 1999).

According to Vicalvi (1997, 2013), the transition from Z2 subzone to Z1 subzone reflects the progressive warming of the Atlantic Ocean after the Glacial Maximum. Towards Z1 subzone, an increase in the percentage of Globorotalia menardii and a progressive decrease in the $\mathrm{Ti} / \mathrm{Ca}$ and $\mathrm{Fe} / \mathrm{Ca}$ ratios are observed, indicating a decrease in continental contribution and an increase in marine influence (Figure 8). This attests to the establishment of a drier and arid climate in northeastern Brazil during the latter part of the Holocene (Cruz et al., 2009). The establishment of drier conditions would be associated with the displacement of the ITCZ south (Arz et al., 1998). This displacement of the ITCZ towards the south would have favored a gradual increase in precipitation in the Amazon region, the south and southeast regions of Brazil, concomitantly with a decrease in precipitation in the northeast region of Brazil (Cruz et al., 2009).

\section{CONCLUSIONS}

From the results obtained in the sedimentological, geochemical and micropaleontological analyzes of the ANP 1011 core collected from the continental slope of the Ceará Basin, it was possible to verify that the studied sedimentary section is composed of siliciclastic, silicibioclastic and biosiliciclastic sediments, deposited in a low intensity hydrodynamic regime.
The association of identified foraminifera is abundant and diverse, comprising 27 taxa of planktic foraminifera. Among the planktic forms in terms of main species: Globigerinoides ruber (white and pink), Trilobatus trilobus, Neogloboquadrina dutertrei, Trilobatus sacculifer. The analysis of the planktic/benthic ratio corroborates to identify and characterize an increase in the flow of organic matter of the euphotic zone in the depth of 67-70 $\mathrm{cm}$ of the studied core, above the PleistoceneHolocene limit.

Through biostratigraphy data in planktic foraminifera, it was possible to characterize the section studied in two biozones ( $Y$ and $\mathrm{Z}$ ) and two subzones (Z2 and Z1) of Pleistocene-Holocene age, with the limit between biozones $\mathrm{Z}$ and $\mathrm{Y}$ found at $82 \mathrm{~cm}$.

Regarding the correlations between elementary ratios, it was possible to conclude that the ratios $\mathrm{Ti} / \mathrm{Ca}$ and $\mathrm{Fe} / \mathrm{Ca}$ have proven to be excellent parameters for assessing trends and inferences of paleoceanographic and paleoclimatic conditions in the study area. Thus, the decrease in the contribution of continental origin and the increase in the marine influence were verified by the occurrence of lower values of the $\mathrm{Ti} / \mathrm{Ca}$ and $\mathrm{Fe} / \mathrm{Ca}$ ratios. This decrease in values is synchronous with the Holocene, interglacial period. In addition, the good correlation between the $\mathrm{Ti} / \mathrm{Ca}, \mathrm{Fe} / \mathrm{Ca}, \mathrm{CaCO}_{3}$ ratios and the biostratigraphic slicing suggests that, in the area analyzed, estimates of the continental influence are reliable.

\section{ACKNOWLEDGMENTS}

This study was funded by the Coordenação de Aperfeiçoamento de Pessoal de Nível Superior Brazil (CAPES) - Financing Code 001. The authors would like to thank the Laboratório de Geologia Marinha e Aplicada (LGMA/UFC), Laboratório de Micropaleontologia Aplicada (LMA/LITPEG/ UFPE), Laboratório de Raios-X da UFC and Laboratório de Paleoceanografia do Atlântico Sul (LaPAS/IOUSP) by the analysis of calcium carbonate. We express our gratitude to the reviewers whose criticism improved the earlier version of this manuscript. 


\section{REFERENCES}

Arz, H.W.; Pätzold, J. \& Wefer, G. 1998. Correlates Millennial-Scale changes in surface hydrography and terrigenous sediment yield inferred from Last-Glacial marine deposits off Northeastern Brazil. Quaternary Research, 50:157-166. doi:10.1006/ qres.1998.1992

Arz, H.W.; Pätzold, J. \& Wefer, G. 1999. Climatic changes the last deglaciation recorded in sediment cores from the northeastern Brazilian Continental Margin. Geo-Marine Letters, 19:209-218. doi:10.1007/s003670050111

Bacon, M.P. 1984. Glacial to interglacial changes in carbonate and clay sedimentation in the Atlantic Ocean estimated from ${ }^{230} \mathrm{Th}$ measurements. Isotope Geoscience, 2:97-111. doi:10.1016/0009-2541(84)90183-9

Bé, A.W.H.; Bishop, J.K.B.; Sverdlove. M.S. \& Gardner, W.D. 1985. Standing stock, vertical distribution and flux of planktonic foraminifera in the Panama Basin. Marine Micropaleontology, 9:307-333. doi:10.1016/0377-8398(85)90002-7

Boltovskoy, E. 1959. Foraminifera as biological indicator in the study of ocean currents. Micropaleontology, 5:473-481. doi: $10.2307 / 1484129$

Boltovskoy, E. 1970. Massas de agua (caracteristica, distribución, movimientos) en la superficie del Atlántico sudoeste, según indicadores biológicos - foraminiferos. Buenos Aires, Secretaria de Marina, Servicio de Hidrografia Naval,100 p.

Bond, G.; Heinrich, H.; Broecker, W.; Labeyrie, L.; Mcmanus, J.; Andrews, J.; Huon, S.; Jantschik, R.; Clasen, S. \& Simet, C. 1992. Evidence for massive discharges of icebergs into the North Atlantic Ocean during the last glacial period. Nature, 360:245-249. doi:10.1038/360245a0

Bouchez, J.; Gaillardet, J.; France-Lanord, C.; Maurice, L. \& Dutra-Maia. P. 2011. Grain size control of river suspended sediment geochemistry: clues from Amazon River depth profiles. Geochemistry, Geophysics, Geosystems, 12:Q03008. doi:10.1029/2010GC003380

Bradley, R.S. 2015. Paleoclimatology reconstructing climates of the Quaternary. $3^{\text {rd }}$ ed. Oxford, Elsevier, 675 p.

Broecker, W. \& Pena, L.D. 2014. Delayed Holocene reappearance of G. menardii. Paleoceanography and Paleoclimatology, 29:291-295. doi:10.1002/2013PA002590

Burns, S.J. \& Maslin, M.A. 1999. Composition and circulation of bottom water in the western Atlantic Ocean during the last glacial, based on pore-water analyses from the Amazon Fan. Geology, 27:1011-1014. doi:10.1130/0091-7613(1999)027<1011:CAC $O B W>2.3 . C O ; 2$

Cheng, H.; Fleitmann, D.; Edwards, R.E.; Wang, X.; Cruz, F.W.; Auler, A.S.; Mangini, A.; Wang, Y.; Kong, X.; Burns, S.J. \& Matter, A. 2009. Timing and structure of the $8.2 \mathrm{kyr}$ B.P. event inferred from $\delta 180$ records of stalagmites from China, Oman, and Brazil. Geology, 37:1007-1010. doi:10.1130/G30126A.1

Clark, P.U.; Pisias, N.G.; Stocker, T.F. \& Weaver, A.J. 2002. The role of the thermohaline circulation in abrupt climate change. Nature, 415:863-869. doi:10.1038/415863a

Conan, S.M.-H.; Ivanova, E.; Brummer, G.-J. 2002. Quantifying carbonate dissolution and calibration of foraminiferal dissolution indices in the Somali Basin. Marine Geology, 182:325-349. doi:10.1016/S0025-3227(01)00238-9

Costa, I.G.; Beltrami, C.V. \& Alves, L.E.M. 1990. A evolução tectono-sedimentar e o "habitat" do óleo na Bacia do Ceará. Boletim de Geociências da Petrobras, 4:65-74.
Costa, K.B.; Camillo, E.; Santarosa, A.C.A.; Iwai, F.S.; De Quadros, J.P.; Leipnitz, I.I. \& Toledo, F.A.D.L. 2018. Menardiiform planktonic foraminifera stratigraphy from Middle Pleistocene to Holocene in the western South Atlantic. Revista Brasileira de Paleontologia, 21:225-237. doi:10.4072/rbp.2018.3.03

Cruz Jr., F.W.; Burns, S.J.; Karmann, I.; Sharp, W.D. \& Vuille, M. 2006. Reconstruction of regional atmospheric circulation features during the late Pleistocene in subtropical Brazil from oxygen isotope composition of speleothems. Earth and Planetary Science Letters, 248:495-507. doi:10.1016/j.epsl.2006.06.019

Cruz, F.W.; Vuille, M.; Burns, S.J.; Wang, X.; Cheng, H.; Werner, M.; Edwards, R.L.; Karmann, I.; Auler, A.S. \& Nguyen, H. 2009. Orbitally driven east west antiphasing of South American precipitation. Nature Geosciences, 2:210-214. doi:10.1038/ ngeo444

Cullen, J.L. 1981. Microfossil evidence for changing salinity patterns in the Bay of Bengal over the last 20.000 years. Palaeogeography, Palaeoclimatology, Palaeoecology, 35:315356. doi:10.1016/0031-0182(81)90101-2

Culver, S.J. 1988. New foraminiferal depth zonation of the northwestern Gulf of Mexico. Palaios, 3:69-85. doi:10.2307/3514545.

Dajoz, R. 1983. Ecologia Geral. $4^{\text {th }}$ ed. Petrópolis, Vozes, 472 p.

Damuth, J.E. 1973. The western Equatorial Atlantic: morphology, Quaternary sediments, anticlimactic cycles. Columbia University, $\mathrm{PhD}$ Thesis, $602 \mathrm{p}$.

Deplazes, G.; Lückge, A.; Peterson, L.C.; Timmermann, A.; Hamann, Y.; Hughen, K.A.; Röhl, U.; Laj, C.E.; Cane, M.A.; Sigman, D.M. \& Haug, G.H. 2013. Links between tropical rainfall and North Atlantic climate during the last glacial period. Nature Geoscience, 6:213-217. doi: 10.1038/ngeo1712

Elliot, M.; Labeyrie, L. \& Duplessy, J.C. 2002. Changes in North Atlantic deep-water formation associated with the DansgaardOeschger temperature oscillation (60-10 ka). Quaternary Science Reviews, 21:1153-1165. doi:10.1016/S0277-3791(01)00137-8

Ericson, D.B. \& Wollin, G. 1968. Pleistocene climates and chronology in deep-sea sediments. Science, 162:1227-1234. doi:10.1126/science.162.3859.1227

Heinrich, H. 1988. Origin and consequences of cyclic ice rafting in the northeast Atlantic Ocean during the past 130,000 years. Quaternary Research, 29:142-152. doi:10.1016/00335894(88)90057-9

Hemleben, C.; Spindler, M.E. \& Emerson, O.R. 1989. Modern Planktonic Foraminifera. Berlin Heidelberg, Springer-Verlag, $363 \mathrm{p}$.

Henry, L.G.; Mcmanus, J.F.; Curry, W.B.; Roberts, N.L.; Piotrowski, A.M. \& Keigwin, L.D. 2016. North Atlantic Ocean circulation and abrupt climate change during the last glaciation. Science, 353:470-474. doi:10.1126/science.aaf5529

Hilbrecht, H. 1997. Morphological gradation and ecology in Neogloboquadrina pachyderma and N. dutertrei (planktic foraminifera) from core top sediments. Marine Micropaleontology, 31:31-43.

Hodell, D.A.; Charles, C.D. \& Sierro, F.J. 2001. Late Pleistocene evolution of the ocean's carbonate system. Earth and Planetary Science Letters, 192:109-124. doi:10.1016/S0012821X(01)00430-7

Jaeschke, A.; Rühlemann, C.; Arz, H.; Heil, G. \& Lohmann, G. 2007. Coupling of millennial-scale changes in sea surface temperature and precipitation off northeastern Brazil with high-latitude climate shifts during the last glacial period. Paleoceanography, 22:PA4206. doi:10.1029/2006PA001391 
Johns, W.E.; Lee, T.N.; Beardsley, R.C.; Candela, J.; Limeburger, R. \& Castro, B. 1998. Annual cycle and variability of the North Brazil Current. Journal of Physical Oceanography, 28:103-128. doi:10.1175/1520-0485(1998)028<0103:ACAV $O T>2.0 . C O ; 2$

Killops, S.D. \& Killops, V. 2005. Introduction to organic geochemistry. $2^{\text {nd }}$ ed. Massachusetts, Wiley-Blackwell, $408 \mathrm{p}$.

Loeblich, A.R. \& Tappan, H. 1988. Foraminiferal genera and their classification. New York, Van Nostrand Reinhold, 970 p.

Lutze, G.F. \& Coulbourn, W.T. 1983. Recent benthic foraminifera from the continental margin of northwest Africa: community structure and distribution. Marine Micropaleontology, 8:361401. doi:10.1016/0377-8398(84)90002-1

Maslin, M.A. 1995. Changes in North Atlantic deep-water formation associated with the Heinrich Events. Naturwissenschaften, 82:330-333.

Maslin, M; Seidov, D. \& Lowe, J. 2001. Synthesis of the nature and causes of rapid climate transitions during the Quaternary. In: D. Seidov; B. Hauot \& M. Maslin (eds.) The oceans and rapid climate change: past, present, and future, AGU, p. 9-52.

Mcmanus, J.F.; Francois, R.; Gherardi, J.M.; Keigwin, L.D. \& Brown-Leger, S. 2004. Collapse and rapid resumption of Atlantic meridional circulation linked to deglacial climate changes. Nature, 428:834-837. doi:10.1038/nature02494

Murray, W.J. \& Alve, E. 2002. Benthic Foraminifera as indicators of environmental change: marginal-marine, shelf and upper-slope environments. In: K.S. Haslett (ed.) Quaternary Environmental Micropaleontology, Edward Arnold, p. 59-90.

Nagai, R.H.; Sousa, S.H.M.; Burone, L. \& Mahiques, M.M. 2009. Paleoproductivity changes during the Holocene in the inner shelf of Cabo Frio, southeastern Brazilian continental margin: benthic foraminifera and sedimentological proxies. Quaternary International, 206:62-71. doi:10.1016/j. quaint.2008.10.014

Peterson, L.C.; Haug, G.H.; Hughen, K.A \&, Röhl, U. 2000. Rapid changes in the hydrologic cycle of the tropical Atlantic during the Last Glacial. Science, 290:1947-1951. doi:10.1126/ science.290.5498.1947

Pivel, M.A.G.; Santarosa, A.C.A.; Toledo, F.A.L. \& Costa, K.B. 2013. The Holocene onset in the southwestern South Atlantic. Palaeogeography, Palaeoclimatology, Palaeoecology, 374:164172. doi:10.1016/j.palaeo.2013.01.014

Rao, V.B.; Lima, M.C. \& Franchito, S.H. 1993. Seasonal and interannual variations of rainfall over eastern Northeast Brazil. Journal of Climate, 6:1754-1763. doi:10.1175/15200442(1993)006 < 1754:SAIVOR > 2.0.CO;2

Razik, S.; Chiessi, C.M.; Romero, O.E. \& Von Dobeneck, T. 2013. Interaction of the South American Monsoon System and the Southern Westerly Wind Belt during the last $14 \mathrm{kyr}$. Palaeogeography, Palaeoclimatology, Palaeoecology, 374:2840. doi:10.1016/j.palaeo.2012.12.022

Schiebel, R. \& Hemleben, C. 2017. Planktic Foraminifers in the modern ocean. Berlin Heidelberg, Springer-Verlag, 358 p.

Schott, F.A.; Mccreary, J.P. \& Johnson, G.C. 2004. Shallow overturning circulations of the tropical-subtropical oceans, in earth climate: the ocean-atmosphere interaction. In: C. Wang; S.P. Xie \& J.A. Carton (eds.) Earth's Climate: the oceanatmosphere interaction, AGU, p. 261-304.

Sen Gupta, B.K. 1999. Systematics of Modern Foraminifera. In: Sen Gupta, B.K. (ed.) Modern Foraminifera, Kluwer Academic Publishers, p. 7-36.
Shepard, F.P. 1954. Nomenclature based on sand-silt-clay ratios. Journal Sedimentary Petrology, 24:151-158. doi:10.1306/ D4269774-2B26-11D7-8648000102C1865D

Silveira, I.C.A.; Calado, L.; Castro, B.M.; Cirano, M.; Lima, J.A.M. \& Mascarenhas, A.D.S. 2004. On the baroclinic structure of Brazil Current - Intermediate Western Boundary Current system at $22^{\circ}-23^{\circ} \mathrm{S}$. Geophysical Research Letters, 31:14308. doi:10.1029/2004GL020036

Suess, H.E. 1956. Absolut chronology of the last glaciation. Science, 123:355-357. doi:10.1126/science.123.3192.355

Talley, L.D.; Pikard, G.L.; Emery, W.J.; Swift, J.H. 2011. Descriptive Physical Oceanography: an introduction. London, Academic press, $560 \mathrm{p}$.

Tinoco, I.M. 1980. Foraminíferos planctônicos dos sedimentos superficiais da margem continental dos estados de Alagoas e Sergipe (nordeste do Brasil). Academia Brasileira Ciências, 52:539-553.

Tinoco, I.M. 1985. Foraminíferos planctônicos dos sedimentos superficiais da margem continental do estado do Pará e do Território do Amapá. In: CONGRESSO BRASILEIRO PALEONTOLOGIA/ESTRATIGRAFIA, 8, 1985. Anais, Rio de Janeiro, p. 507-516.

Toledo, F.A.L.; Costa, K.B. \& Pivel, M.A.G. 2007. Salinity changes in the western tropical South Atlantic during the last $30 \mathrm{kyr}$. Global and Planetary Change, 57:383-395. doi:10.1016/j. gloplacha.2007.01.001

Vicalvi, M.A. 1997. Zoneamento bioestratigráfico e paleoclimático dos sedimentos do Quaternário Superior do talude da Bacia de Campos, RJ, Brasil. Boletim de Geociências da Petrobras, 11:132-165.

Vicalvi, M.A. 2013. Distribuição estratigráfica quantitativa de foraminíferos planctônicos no Quaternário da margem continental do Sudeste brasileiro. Boletim de Geociências da Petrobras, 21:357-368.

Vicalvi, M.A. \& Palma, J.J.C. 1980. Bioestratigrafia e taxas de acumulação dos sedimentos quaternários do talude e sopé continental entre a foz do Rio Gurupi (MA) e Fortaleza (CE). Boletim Técnico da Petrobras, 23:3-11.

Vilela, C.G. \& Maslin, M. 1997. Benthic and planktonic foraminifers, and stable isotopic analysis of mass-flow sediments in the amazon fan. Scientific Results, Ocean Drilling Program, 155:335-351. doi:10.2973/odp.proc.sr.155.219.1997

Vital, H.; Esteves, L.S.; Araújo, T.C.M. \& Patchineelam, S.M. 2005. Oceanografia geológica e geofísica da Plataforma Continental Brasileira. In: C.R.G. Souza; K. Suguio; A.M.S. Oliveira \& P.E. Oliveira (orgs.) Quaternário do Brasil, Holos, p. 153-175.

Voelker, A.H.L. 2002. Global distribution of centennial-scale records for Marine Isotope Stage (MIS) 3: a database. Quaternary Science Review, 21:1185-1212. doi:10.1016/S0277-3791(01)00139-1

Volat, J.L.; Pastouret, L. \& Vernaud-Graggini, C. 1980. Dissolution and carbonate fluctuations in Pleistocene deep-sea cores: a review. Marine Geology, 34:1-28.

Wang, X.; Auler, A.S.; Edwards, R.L.; Cheng, H.; Cristalli, P.S.; Smart, P.L.; Richards, D.A. \& Shen, C. 2005. Wet periods in Northeastern Brazil over the past $210 \mathrm{kyr}$ linked to distant climate anomalies. Nature, 432:740-743. doi:10.1038/nature03067

Wang, X.; Auler, A.S.; Edwards, R.L.; Cheng, H.; Ito, E.; Solheid, M.; Wang, Y.J. \& Kong, X.G. 2007. Millennialscale precipitation changes in southern Brazil over the past 90,000 years. Geophysical Research Letters, 34:L23701. doi:10.1029/2007GL031149 
Weldeab, S.; Schneider, R.R. \& Köllinga, M. 2006. Deglacial sea surface temperature and salinity increase in the western tropical Atlantic in synchrony with high latitude climate instabilities. Earth and Planetary Science Letters, 241:699-706. doi:10.1016/j.epsl.2005.11.012

Wilson, B.; Hayek, L-A.C. \& Pivel, M.A.G. 2019. Quantifying and comparing rates of dissolution and assemblage turnover among planktonic foraminifera; a case study from the Upper Quaternary in ODP Hole 926A, Ceara Rise, western tropical Atlantic Ocean. Micropaleontology, 65:473-483.

Zerfass, G.S.A. 2019. Guia ilustrado dos foraminiferos planctônicos (Oligoceno-Recente) da Bacia de Pelota e Elevação do Rio Grande. Petrobras, 237 p.

Zhang, Y.; Chiessi, C. M.; Mulitza, S.; Sawakuchi, A.O.; Häggi, C.; Zabel, M.; Portilho-Ramos, R.C.; Schefuß, E.; Crivellari, S. \& Wefer, G. 2017. Different precipitation patterns across tropical South America during Heinrich and Dansgaard-Oeschger stadials. Quaternary Science Reviews, 177:1-9. doi:10.1016/j. quascirev.2017.10.012
Zhang, D.; Msadek, R.; Mcphaden, M.J. \& Delworth, T. 2011. Multidecadal variability of the North Brazil Current and its connection to the Atlantic meridional overturning circulation. Journal of Geophysical Research Letters, 116:C04012. doi:10.1029/2010JC006812

Received in 29 July, 2020; accepted in 03 May, 2021. 
Appendix 1. List of planktic foraminifera taxa recovered in the ANP 1011 core. The taxonomic concepts used in this study follow the work of Loeblich \& Tappan (1988), Schiebel \& Hemleben (2017), and Zerfass (2019).

Candeina nitida d’Orbigny, 1839

Globigerinita glutinata (Egger, 1895)

Globigerinita sp. (Brönnimann, 1951)

Globigerina bulloides d'Orbigny, 1826

Globigerina falconensis Blow, 1959

Globigerinoides conglobatus (Brady, 1879)

Globigerinoides ruber (d'Orbigny, 1839)

Globigerinoides ruber (d'Orbigny) form pyramidalis (van den Broeck, 1876)

Globoturborotalita rubescens (Hofker, 1956)

Trilobatus sacculifer (Brady, 1877)

Trilobatus trilobus (Reuss, 1850)

Globigerinella calida (Parker, 1962)

Globigerinella siphonifera (d'Orbigny, 1839)

Globorotalia crassaformis viola (Galloway \& Wissler, 1927)

Globoconella inflata (d'Orbigny, 1839)

Globorotalia menardii menardii (d’Orbigny, 1865)

Globorotalia tumida (Brady, 1877)

Globorotalia aff. fimbriata [Globorotalia menardii var. fimbriata (Brady, 1884)].

Globorotalia theyeri Fleisher, 1974

Neogloboquadrina dutertrei (d’Orbigny, 1839)

Neogloboquadrina incompta (Cifelli, 1961)

Neogloboquadrina pachyderma (Ehrenberg, 1861)

Globorotalia truncatulinoides (d'Orbigny, 1839)

Orbulina universa d'Orbigny, 1839

Pulleniatina obliquiloculata (Parker \& Jones, 1865)

Pulleniatina primalis Banner \& Blow, 1967

Sphaeroidinellopsis Banner \& Blow, 1959 